\title{
Hypertension, Diabetes and Overweight: Looming Legacies of the Biafran Famine
}

\author{
Martin Hult ${ }^{19}$, Per Tornhammar ${ }^{19}$, Peter Ueda ${ }^{19}$, Charles Chima ${ }^{3}$, Anna-Karin Edstedt Bonamy ${ }^{2}$, \\ Benjamin Ozumba ${ }^{3}$, Mikael Norman ${ }^{1 *}$
}

1 Department of Clinical Science, Intervention and Technology, Karolinska Institute, Stockholm, Sweden, 2 Department of Women's and Children's Health, Karolinska Institute, Stockholm, Sweden, 3 University of Nigeria Teaching Hospital, Enugu, Nigeria

\begin{abstract}
Background: Sub-Saharan Africa is facing rapidly increasing prevalences of cardiovascular disease, obesity, diabetes and hypertension. Previous and ongoing undernutrition among pregnant women may contribute to this development as suggested by epidemiological studies from high income countries linking undernutrition in fetal life with increased burden of non-communicable diseases in later life. We undertook to study the risks for hypertension, glucose intolerance and overweight forty years after fetal exposure to famine afflicted Biafra during the Nigerian civil war (1967-1970).

Methods and Findings: Cohort study performed in June 27-July 31, 2009 in Enugu, Nigeria. Adults $(n=1,339)$ born before (1965-67), during (1968-January 1970), or after (1971-73) the years of famine were included. Blood pressure (BP), random plasma glucose (p-glucose) and anthropometrics, as well as prevalence of hypertension (BP $>140 / 90 \mathrm{mmHg}$ ), impaired glucose tolerance (IGT; p-glucose 7.8-11.0 mmol/l), diabetes (DM; p-glucose $\geq 11.1 \mathrm{mmol} / \mathrm{l})$, or overweight $\left(\mathrm{BMI}>25 \mathrm{~kg} / \mathrm{m}^{2}\right)$ were compared between the three groups. Fetal-infant exposure to famine was associated with elevated systolic $(+7 \mathrm{mmHg} ; \mathrm{p}<0.001)$ and diastolic $(+5 \mathrm{mmHg} ; \mathrm{p}<0.001) \mathrm{BP}$, increased $\mathrm{p}$-glucose $(+0.3 \mathrm{mmol} / \mathrm{L} ; \mathrm{p}<0.05)$ and waist circumference $(+3 \mathrm{~cm}, \mathrm{p}<0.001)$, increased risk of systolic hypertension (adjusted OR 2.87; 95\% Cl 1.90-4.34), IGT (OR 1.65; $95 \% \mathrm{Cl} 1.02-2.69)$ and overweight (OR 1.41; 95\% Cl 1.03-1.93) as compared to people born after the famine. Limitations of this study include the lack of birth weight data and the inability to separate effects of fetal and infant famine.

Conclusions: Fetal and infant undernutrition is associated with significantly increased risk of hypertension and impaired glucose tolerance in 40-year-old Nigerians. Prevention of undernutrition during pregnancy and in infancy should therefore be given high priority in health, education, and economic agendas.
\end{abstract}

Citation: Hult M, Tornhammar P, Ueda P, Chima C, Edstedt Bonamy A-K, et al. (2010) Hypertension, Diabetes and Overweight: Looming Legacies of the Biafran Famine. PLoS ONE 5(10): e13582. doi:10.1371/journal.pone.0013582

Editor: J. Jaime Miranda, Universidad Peruana Cayetano Heredia, Peru

Received July 5, 2010; Accepted September 19, 2010; Published October 22, 2010

Copyright: (C) 2010 Hult et al. This is an open-access article distributed under the terms of the Creative Commons Attribution License, which permits unrestricted use, distribution, and reproduction in any medium, provided the original author and source are credited.

Funding: Funding was received from the Karolinska Institute, Swedish International Development Cooperation Agency and Carl-Eriks Levins Foundation. Funding was unrestricted and the funders had no role in the study design, data collection, analysis, decision to publish or preparation of the manuscript.

Competing Interests: The authors have declared that no competing interests exist.

* E-mail: mikael.norman@ki.se

9 These authors contributed equally to this work.

\section{Introduction}

Sub-Saharan African countries are in a process of a rapid epidemiological transition, away from infectious diseases, towards non-communicable diseases as leading causes of death [1]. Such transition in disease pattern is generally attributed to rural-tourban shifts in adult lifestyle and typically involves changes in diet, cigarette smoking and lack of exercise [2]. There is a growing body of evidence however, suggesting that increased susceptibility to chronic diseases in adulthood has a developmental basis, originating in fetal life [3,4]. The rapid development and shaping of the phenotype that occurs in utero is highly sensitive to environmental - in particular, nutritional - perturbations, leading to reduced functional capacity, altered metabolism and hormone production $[3,5]$. This is considered an important underlying mechanism [3,4] explaining why adults born small - a proxy for fetal starvation - are at increased risks for cardiovascular diseases and diabetes $[6,7]$.
The role of undernutrition during gestation for future health in children and adults has previously been evaluated in different countries [8-24]. However, besides data from European birth cohorts from the second world war [9-12,19,21-24], there is very limited information on the effects of fetal famine from other parts of the world, and with a follow-up time reaching beyond young adulthood. In particular, there is a lack of long-term follow-up data from sub-Saharan Africa, a continent with an unresolved situation with ongoing maternal-infant undernutrition, a recent and quick introduction of obesity-enhancing lifestyle factors and a rapidly increasing prevalence of cardiovascular disease, diabetes and hypertension [1,25-27]. Therefore, the strength of a link between poor fetal nutrition and later adult diseases, would be of great interest to clarify in this part of the world also.

The study aim was to determine the risks for hypertension, diabetes and overweight forty years after fetal and infant exposure to the famine hitting Biafra during the Nigerian civil war (19671970) [28]. 


\section{Methods}

This observational study is based on the findings from a cohort of 1,339 subjects, belonging to the ethnic group Igbo, who were born between 1965 and 1973, i.e., before, during and after the Biafran famine.

\section{Ethics statement}

Ethical approval for the study was given by the Ethics Committee of the University of Nigeria Teaching Hospital, Enugu, and the Regional Ethical Vetting Board, Stockholm, Sweden. Informed consent (verbal and written in English, translated to Igbo if necessary) was obtained from all participants.

\section{The Nigerian civil war and the Biafran famine}

The Nigerian civil war broke out on 6 July 1967, after the Igbo people in the south-eastern provinces had declared independence as the Republic of Biafra. The war was a culmination of ethnic, economic, and religious tensions among the various peoples of Nigeria. Disapproving of the secession, Nigerian forces rapidly pushed the Biafrans back into a small enclave. Inflow of food to this enclave was cut off. The result was extensive famine among the Igbos, regarded as one of the great nutritional disasters of modern times [28]. The war ended on 15 January 1970.

Of the 1 to 3 million Igbos that are estimated to have lost their lives, only a small fraction $(10 \%)$ died of military violence. The majority succumbed to starvation. The nutritional emergency was most critical in the Biafran enclave, in which approximately 7 million people - mostly refugees - resided. In August 1968 the first international relief operations were launched but the amount of food provided was clearly not sufficient and the great majority of the Igbos did not get access to this relief food [29].

\section{Setting and participants}

This follow-up study took place between June 27 and July 31, 2009. All shops at the six major market places of Enugu, the former Biafran capital, were systematically covered. People at the markets were actively contacted at their work place. The selection of participants was restricted to men and non-pregnant women who knew they were born in the southeast of Nigeria between 1965 and 1973. All subjects reported year of birth and 73\% reported at least month and year. To confirm the birth year specified by the subject, we asked each person for a short review of his or her family history during the Nigerian civil war. The vast majority (more than 90\%) of eligible subjects accepted participation in the study. It was not possible to do a systematic categorization of those who declined.

Data collection was conducted by MH, PT, PU, as well as doctors and medical students from the University of Nigeria Teaching Hospital (please see acknowledgements). Recruitment was performed by all team members, whereas measurements of blood pressure and p-glucose were obtained by a smaller group $(n=7)$ of specially trained investigators. Subjects were asked about level of education, current smoking, previously diagnosed hypertension or diabetes mellitus, and treatment for these conditions. Level of education was categorized as none, primary, secondary or higher education. There was no available information on birth weight or infant nutrition.

All measurements were performed according to predefined standard operating procedures. Participants were instructed to rest seated for at least five minutes before blood pressure (BP) and heart rate were measured. Two readings were taken three minutes apart in the left arm using a validated [30] automated oscillometric device (Omron M6 HEM-7001-E, Omron Corporation, Kyoto,
Japan). A third reading was taken if the first and second BP differed more than five $\mathrm{mmHg}$ and mean systolic and diastolic values were calculated and defined as the subject's BP. Subjects having a systolic $\mathrm{BP} \quad(\mathrm{SBP}) \geq 140 \mathrm{mmHg}$, or a diastolic BP $(\mathrm{DBP}) \geq 90 \mathrm{mmHg}$ or who had a normal blood pressure but were pharmacologically treated for hypertension $(n=41$ of 1,339$)$, were categorized as hypertensive. Subjects having a $\mathrm{SBP} \geq 160 \mathrm{mmHg}$, and a $\mathrm{DBP} \geq 100 \mathrm{mmHg}$, were categorized as severely hypertensive. Random plasma glucose (p-glucose) was measured with a minimally invasive sampling technique (Abbott Freestyle Lite, Abbott Diabetes Care Ltd, Oxon, UK). A random p-glucose of $11.1 \mathrm{mmol} / \mathrm{l}$ or higher was classified as diabetes mellitus and impaired glucose tolerance (IGT) was defined as random p-glucose between 7.8 and $11.0 \mathrm{mmol} / \mathrm{l}$ [31]. A subgroup $(\mathrm{n}=75)$ reported no food intake for at least 8 hours prior to investigation. In this group IGT was defined as p-glucose between 6.1 and $6.9 \mathrm{mmol} / \mathrm{l}$ and diabetes mellitus as a p-glucose $\geq 7.0 \mathrm{mmol} / \mathrm{l}$ [31]. Height and weight were obtained from all subjects using height sticks and digital scales, respectively, and body mass index (BMI) was calculated. Overweight was defined as a BMI over $25 \mathrm{~kg} / \mathrm{m}^{2}$ and obesity as BMI over $30 \mathrm{~kg} / \mathrm{m}^{2}$. Waist circumference was measured with a measuring tape placed around the abdomen at the level of the upper hip bone, and considered as an indicator of central obesity.

All participants were briefly counselled about their current health status. Hypertensive or glucose intolerant subjects were referred to the University of Nigeria Teaching Hospital for further investigation and treatment.

\section{Categorization according to exposure to famine}

Subjects born between 1965 and 1967 were categorized as being exposed to famine in early childhood. Subjects born between 1968 and January 1970 (end of war) were categorized as being exposed to famine in fetal life and in infancy. Subjects born immediately after the surrender of Biafra were left uncategorized because of uncertainties in their exposure to famine and local variations in nutritional relief. Accordingly, subjects born between 1971 and 1973 and after the transitional period were categorized as being unexposed to famine.

Efforts to limit any potential bias included investigator-driven recruitment of participants (in contrast to subjects actively seeking participation in the study), direct assessments of outcomes with non-operator dependent methods and predefined standardized operational procedures applied by all data collectors.

\section{Statistical methods}

We aimed to include 630 individuals in each group, based on an assumption of a standard deviation of $19 \mathrm{mmHg}$ and a group difference in systolic blood pressure of $3 \mathrm{mmHg}$ or more, given $80 \%$ power and a statistical significance level of 0.05 . Because of exhausted recruitment at the six study markets, data collection was ended when 1,339 subjects had been included in the study. All subjects were included in logistic regression analyses according to year of birth whereas in group wise logistic regression analyses, the 173 subjects born during the transition from famine to nutritional relief, i.e., from February to December 1970, were excluded.

Data are presented as means (SD), proportions (\%) and odds ratios $(95 \%$ CI). Group differences were tested using ANOVA and chi-squared test. Logistic and linear regression analyses were used to calculate odds ratios (OR) and for evaluation of relations between exposure (fetal-infant famine), potential confounders (sex, smoking, educational level) and outcomes (blood pressure, pglucose, and BMI). As several previous reports have shown that the associations between early life exposures and adult outcomes 
vary in relation to sex and adult body size [9,10,14,22,32-34], we also stratified our analyses on sex and BMI. A p-value $<0.05$ was considered as statistically significant. Analyses were performed using STATA/IC 11.0 (Stata Corp LP, TX, US). To evaluate gender differences analyses stratified according to sex were also performed.

\section{Results}

Age differed among the three groups due to inclusion criteria. The proportion of men varied between 66 and $74 \%$ in the three groups and was highest in the group born after the famine. Smoking occurred predominantly in men and the proportion of smokers differed in the three groups, Table 1. Educational levels were found to be distributed equally between groups $(p=0.38)$ and overall, no education was found in $1 \%$, primary in $34 \%$, secondary in $52 \%$ and higher education in $13 \%$.

\section{Famine and risk for hypertension}

SBP and DBP were higher after fetal-infant exposure to famine, as compared to the other two groups, i.e., those exposed in early childhood as well as those that were born after the famine, i.e., were unexposed, Table 1 . In addition, the OR's for a SBP and DBP in the hypertensive range were significantly higher for the group exposed to fetal-infant famine, Table 2.

In linear regression analyses, $\mathrm{SBP}$ and $\mathrm{DBP}$ were associated with BMI $(\beta=0.49, r=0.13, p<0.001$ and $\beta=0.54, r=0.21$, $\mathrm{p}<0.001$, respectively) and male sex $(\beta=3.3, \mathrm{r}=0.08, \mathrm{p}=0.003$ and $\beta=-1.46, r=0.06, p=0.05$, respectively), but not with smoking. After adjusting for BMI odds ratios for SBP and DBP in the hypertensive range were of the same magnitude as before adjustment and still significantly higher for the group exposed to fetal-infant famine. In addition, analyses stratified on sex showed that exposure to famine in fetal life and infancy was a risk factor for SBP and DBP in the hypertensive range in both women and men. The OR $(95 \%$ CI) for severe hypertension in the group exposed to fetal-infant famine was $2.82(1.18-6.73)$ in men and $2.30(0.65-8.10)$ in women, Table 2.

Odds ratios for high SBP $(\geq 140 \mathrm{mmHg}$ ) according to each year of birth and with 1972 as reference year $(\mathrm{OR}=1)$, are presented in Figure 1. The figure shows that famine in fetal-infant life (birthyear 1968 and 1969) resulted in a three to four fold increase in risk for an adult SBP in the hypertensive range, both in women and men.

Odds ratios for high $\mathrm{SBP}(\geq 140 \mathrm{mmHg})$ in relation to exposure group (childhood famine, fetal-infant famine and unexposed) and stratified on current overweight $(\mathrm{BMI} \geq 25)$, are presented in Table 3. Formal statistical testing for an interaction between early exposure to famine by sex and adult overweight was not significant, suggesting that the effects of early famine and current overweight on SBP were additive to each other.

\section{Famine and risk for impaired glucose tolerance/diabetes}

Random p-glucose was higher in adults exposed to famine in fetal-infant life, Table 1 . The crude odds ratio for both IGT and diabetes was significantly higher for the group exposed to fetalinfant famine in comparison to the subjects born after the famine. Exposure to famine in early childhood did not increase the risk for IGT and diabetes in later life, Table 2.

In linear regression analyses, random p-glucose was associated with $\operatorname{BMI}(\beta=0.04, \mathrm{r}=0.12, \mathrm{p}<0.001)$ and male sex $(\beta=-0.41, \mathrm{r}=0.10$, $\mathrm{p}=0.001)$. In analyses adjusted for BMI, fetal-infant exposure to

Table 1. Subject characteristics.

\begin{tabular}{|c|c|c|c|c|c|}
\hline & \multirow{3}{*}{$\begin{array}{l}\text { Born 1965-1967 } \\
\text { Famine in } \\
\text { early childhood }\end{array}$} & \multirow{3}{*}{$\begin{array}{l}\text { Born 1968- } \\
\text { January } 1970 \\
\text { Fetal-infant famine }\end{array}$} & \multirow{3}{*}{$\begin{array}{l}\text { Born 1971-1973 } \\
\text { Unexposed }\end{array}$} & \multirow{3}{*}{ P-value } & \multirow{3}{*}{$\begin{array}{l}\text { Feb-Dec } 1970 \\
\text { Transitional } \\
\text { period }\end{array}$} \\
\hline & & & & & \\
\hline & & & & & \\
\hline Number of subjects $(1,339)$ & 388 & 292 & 486 & & 173 \\
\hline Sex, male & $246(66 \%)$ & $189(66 \%)$ & $353(74 \%)$ & 0.01 & 112 (65\%) \\
\hline Age & $43.0(0.8)$ & $40.5(0.6)$ & $37.0(0.8)$ & $\mathrm{N} / \mathrm{A}$ & 39 \\
\hline Smoking, yes (\%) & $46(12 \%)$ & $27(9 \%)$ & $81(17 \%)$ & 0.007 & $19(11 \%)$ \\
\hline \multicolumn{6}{|l|}{ Education, N (\%) } \\
\hline None & $6(2 \%)$ & $4(1 \%)$ & $5(1 \%)$ & 0,38 & $4(2 \%)$ \\
\hline Primary & $138(38 \%)$ & $80(30 \%)$ & $152(33 \%)$ & & $46(28 \%)$ \\
\hline Secondary & $172(48 \%)$ & $152(57 \%)$ & $239(52 \%)$ & & $97(58 \%)$ \\
\hline Higher & $44(12 \%)$ & $33(12 \%)$ & $60(13 \%)$ & & 19 (11\%) \\
\hline \multicolumn{6}{|l|}{ Current data } \\
\hline Systolic blood pressure, $\mathrm{mm} \mathrm{Hg}$ & $125(17)$ & 129 (19) & $122(16)$ & $<0.0001$ & $124(19)$ \\
\hline Diastolic blood pressure, $\mathrm{mm} \mathrm{Hg}$ & $81(11)$ & $84(12)$ & $79(11)$ & $<0.0001$ & $81(12)$ \\
\hline Heart rate, bpm & $75(11)$ & $76(11)$ & $75(11)$ & 0.27 & $77(10)$ \\
\hline Random p-glucose, mmol/l & $6.1(1.6)$ & $6.4(2.0)$ & $6.1(1.8)$ & 0.04 & $6.3(2.6)$ \\
\hline Weight, kg & $76.2(12.9)$ & $78.5(13.4)$ & $77.0(13.4)$ & 0.08 & $76.3(15.4)$ \\
\hline Height, cm & $169(8)$ & $169(8)$ & $170(8)$ & 0.034 & $169(8)$ \\
\hline Waist circumference, $\mathrm{cm}$ & $93(11)$ & $94(13)$ & $91(11)$ & 0.0011 & $92(12)$ \\
\hline BMI, $\mathrm{kg} / \mathrm{m}^{2}$ & $26.7(4.7)$ & $27.5(4.6)$ & $26.5(4.4)$ & 0.016 & $26.6(5.1)$ \\
\hline
\end{tabular}

Data are mean (SD) or number (\%) of subjects. p-values for ANOVA or chi-squared test across groups. Data from transitional period (February 1970-December 1970) not included in the analyses. BMI = body mass index.

doi:10.1371/journal.pone.0013582.t001 


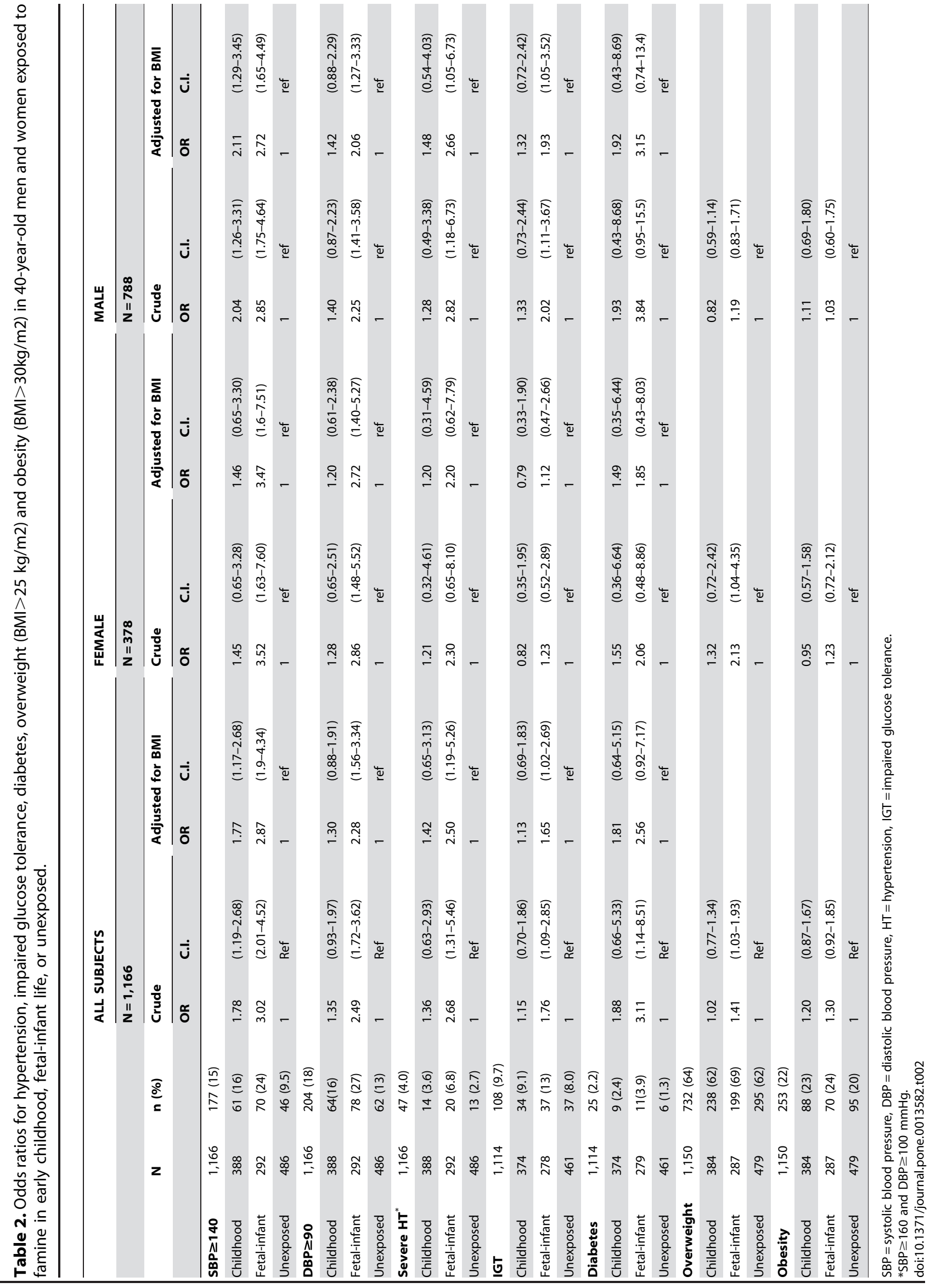




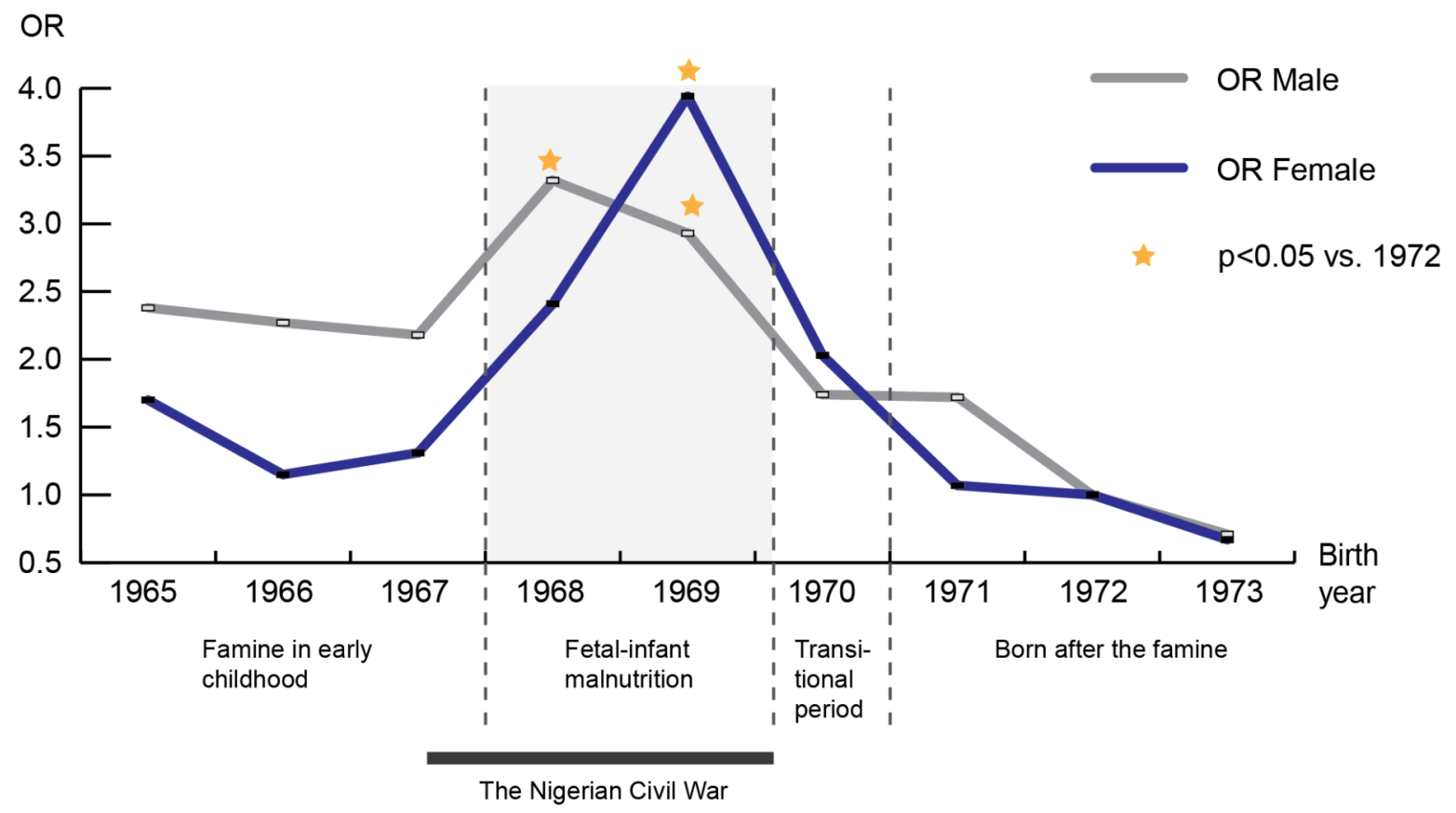

Figure 1. Odds ratios for high systolic ( $\geq 140 \mathrm{mmHg}$ ) blood pressure in men and women at follow-up in 2009 according to year of birth and with 1972 as reference.

doi:10.1371/journal.pone.0013582.g001

famine remained as a risk factor for IGT and diabetes in Nigerian subjects in their forties. Stratified analyses on sex showed that the OR $(95 \%$ CI $)$ for diabetes after exposure to fetal-infant famine was 3.84 (0.95-15.5) in men and $2.06(0.48-8.86)$ in women, Table 2.

\section{Famine and risk for overweight}

The group born after the famine was significantly taller than the other two groups, whereas there were no group differences in weight, Table 1 . Waist circumference and BMI were higher in adults exposed to famine in fetal-infant life, Table 1 . The crude odds ratio for overweight (BMI>25) was significantly higher for the group exposed to fetal-infant famine in comparison to the subjects born after the famine. Stratified analyses on sex showed that this effect was confined to women Table 2.

\section{Discussion}

This study showed higher BP, higher p-glucose and higher weight in middle-aged Nigerian people exposed to severe undernutrition in utero and in infancy. Comparing unexposed offspring with that of starving pregnant women, fetal-infant undernutrition was associated with significant increases in the prevalence of hypertension (from 9.5 to $24 \%$, defined as $\mathrm{SBP} \geq 140 \mathrm{mmHg}$ ) and impaired glucose tolerance or diabetes (from 8.0 to $13 \%$ ). Famine in early childhood was also associated with an increased prevalence of adult blood pressure in the hypertensive range (from 9.5 to $16 \%$ ). Given the additive effects of early famine and adult overweight (Table 3), early undernutrition followed by later overnutrition seem to provide two fundaments for the adverse metabolic and cardiovascular outcomes seen in today's Nigeria, and as also previously described in an Indian cohort (14).

Our results are in line with previous epidemiological and experimental studies suggesting that fetal undernutrition contributes significantly to cardiovascular disease risk in adult life $[3,5,20,35]$. In contrast to observations in European birth cohorts [9-12,19,20-24], the effects of fetal undernutrition seem to be more pronounced and emerge at an earlier age in this sub-

Table 3. Odds ratios (OR) for systolic blood pressure (SBP) $\geq 140 \mathrm{~mm} \mathrm{Hg}$ and impaired glucose tolerance stratified on exposure to early famine and current BMI.

\begin{tabular}{|c|c|c|c|c|c|c|c|}
\hline & \multirow[b]{3}{*}{ BMI } & \multicolumn{6}{|c|}{ GROUP } \\
\hline & & \multicolumn{2}{|c|}{ Childhood Famine } & \multicolumn{2}{|c|}{ Fetal-Infant Famine } & \multicolumn{2}{|c|}{ Unexposed } \\
\hline & & OR & 95\% C.I. & OR & 95\% C.I. & OR & 95\% C.I. \\
\hline \multirow[t]{2}{*}{$S B P \geq 140 \mathrm{~mm} \mathrm{Hg}$} & $\leq 25$ & 2.14 & $(0.88-5.45)$ & 2.49 & $(0.91-6.81)$ & 1 & Ref \\
\hline & $>25$ & 3.95 & $(1.88-9.04)$ & 6.98 & $(3.36-15.84)$ & 2.34 & $(1.10-5.44)$ \\
\hline \multirow[t]{2}{*}{ Impaired glucose tolerance } & $\leq 25$ & 2.58 & $(0.94-7.77)$ & 3.43 & $(1.16-10.48$ & 1 & ref \\
\hline & $>25$ & 2.23 & (0.88-6.39) & 3.57 & $(1.45-10.02)$ & 2.78 & $(1.16-7.66)$ \\
\hline
\end{tabular}

doi:10.1371/journal.pone.0013582.t003 
Saharan cohort. These differences could reflect variations in exposure and population differences. Such an explanation may not necessarily be confined to susceptibility for and degree of fetalinfant undernutrition alone. Accelerated growth in later childhood $[22,32]$ and a high BMI in adult life have previously been found to have a stronger adverse effect on hypertension [33,34] and diabetes $[9,10]$ in people who were small at birth. The mismatch between the environment that people in urban Nigeria now live in, characterized by a high-calorie-high-carbohydrate diet, and the one within which they evolved during the Biafran famine, may therefore be largely responsible for the present increase in disease risks [36]. Our finding of a higher current weight and waist circumference, and a higher BMI in adults exposed to fetal-infant famine (Table 1) imply that accelerated growth later in childhood may be in the pathway between early under-nutrition and later metabolic syndrome. Such an explanation may also be valid for the finding that glucose tolerance and blood pressure in 35-yearold Gambians (predominantly women) who remained fit and lean, showed no association with moderate to severe malnutrition in early life [37]. However, as we found no attenuation of the excess odds for adult hypertension and impaired glucose tolerance after adjusting for current BMI (Table 2), the association between fetalinfant famine and adult metabolic syndrome cannot be attributed to accelerated childhood growth alone [38].

Gender differences in developmental programming have previously been described [32]. In our study, both men and women exposed to fetal-infant undernutrition exhibited higher odds ratios for elevated blood pressure at follow-up. An excess risk for IGT was also found in men whereas power limitations unable conclusions regarding the risk for IGT in women exposed to early famine. Conversely, a significant excess risk for overweight was only seen in women exposed to fetal-infant undernutrition. Although there are reports of increased susceptibility for fetal programming of $\mathrm{BP}$ in males [23,32], sex differences in the association between birth weight and BP have been questioned [39]. Experimental data suggest possible sex specific mechanisms in fetal programming of insulin secretion and insulin resistance [40], mechanisms that may be relevant in explaining our findings of gender differences in glucose tolerance.

The strengths of this study include the design with prospectively set inclusion criteria and active enrolment of a large cohort of customers and traders at markets, i.e., places where many people in the urban areas gather and work, as other sectors of employment and sites for purchasing of everyday goods are not very developed in this part of the world. Thus we believe that the study cohort is representative for urban settings in sub-Saharan Africa and at highest risk for the present epidemic in noncommunicable diseases. Categorization was based on date of birth - i.e., exposure to famine in early life. In addition, since subjects born in the transitional period were excluded, there was no late gestational overlap with famine in the unexposed group. The follow-up time was sufficiently long to establish relations to outcomes that are directly related to adult cardiovascular disease. Finally, we addressed the possibility that smoking confounded our results [41].

Although heritability for birth weight has been estimated to range from $25 \%$ to $40 \%$ [42], and although some experimental data suggest that birth weight may fail to reflect intrauterine factors associated with later disease risk [43], birth weight is the most commonly used proxy for fetal undernutrition. Therefore, a limitation of our study, shared with other famine studies [19,23], is the lack of anthropometric data at birth and in infancy. There are no records from which these data can be retrieved. In addition, we have no data on mother and infant nutrition. Given that inflow of food to Biafra was cut off, it can be assumed that access to infant formula was extremely limited and that most infants were exclusively breastfed.

It is likely that survival of the healthiest pregnant women occurred during the Biafran famine. The most severe cases of fetal and infant undernutrition are also likely to have died prior to follow-up, either in early childhood or from the increasing cardiovascular morbidity reported from adults residing in the area [25]. Some misclassification may have occurred as the nutritional situation of Biafra gradually deteriorated, making it difficult to pinpoint the start of famine. If anything, these limitations may have introduced a conservative bias into our study, underestimating the true long-term effects of undernutrition in fetal life and in infancy.

Before the war, Biafra differed from most developing nations because it had a good supply of food and water, and sound public health policies with many physicians, nurses, hospitals, and clinics [44]. Already months after the war, there are reports of vast improvement in the nutritional situation [28]. Our results are therefore most likely reflecting differences in adult health outcomes after severe early famine as compared to a significantly better nutritional situation in early life.

The external validity of data from a convenience sample from market places can also be discussed. The method of recruiting participants will have missed subsistence farmers and others not attending the markets, whose nutritional status and other factors are likely to differ from market people. We note that the prevalences of hypertension, diabetes and obesity reported herein are similar to those reported from comparable urban and rural Nigerian cohorts $[45,46]$.

The study design, i.e., comparing long-term outcomes in people born before, during or after famine, has previously been used [912]. By inclusion, the subjects in the unexposed group were youngest. As the prevalence of hypertension and glucose intolerance increases with age, some associations with birth year might be expected. However, given the size of the effect and that the OR's for all outcomes after fetal-infant famine were significantly lower not only in younger, but also in older people, trends in disease-risks over time and cohort effects cannot be the only explanation for our findings.

Previous studies indicate that a nutritional insult - during gestation or the first few months of postnatal life - may be important for later outcome and disease risk [9,11]. Although the resolution and exposure data of this study do not allow for a detailed analysis of the timing of the insult, the striking doseresponse effect found between birth during years of famine and over-risk for hypertension in adult life (Figure 1) suggests a causal relationship. The Biafran famine was characterized by a severe scarcity of proteins, manifested in the vast number of infants and children suffering from kwashiorkor [28]. Experimental models suggest that protein deficit in utero may programme abnormal glucose homeostasis and vascular endothelial dysfunction, whereas results are less consistent with regard to programming of high blood pressure $[35,43]$. Besides the nutritional insult, pregnant women in former Biafra were living under conditions of war. Such stress for mothers and infants could also contribute to higher blood pressure in later life [47].

The implications of our findings are important. On a population level, a $3.3 \mathrm{mmHg}$ increase in mean $\mathrm{SBP}$ and $2 \mathrm{mmHg}$ in DBP can be translated into an estimated increase in cardiovascular deaths by $25 \%$ and stroke by $32 \%$ [48]. Given the combination of large blood pressure effects and increased rates of glucose intolerance resting on a basis of prevalent obesity before middle age (Table 3), which is characteristic for Nigeria today, it is not 
surprising that disability and deaths from stroke and coronary heart disease are rapidly increasing. To adequately address this trend in non-communicable diseases on a community level requires a developed health care infrastructure providing life-long treatment and follow-up. The increasing burden of chronic diseases therefore poses a massive challenge to the already crippled health care systems of sub-Saharan Africa.

In summary, our study demonstrates a fetal-infant contribution to adult hypertension and glucose intolerance in an African cohort. It can be assumed that fetal and infant undernutrition is a significant contributor to the increasing prevalence of hypertension and glucose intolerance also in other parts of sub-Saharan Africa. Therefore, prevention of fetal and infant undernutrition should be given high priority in national health, education, and economic agendas to limit the increase of non-communicable diseases in many African countries. Given that the highest risk for hypertension was found in those undernourished in early life and then growing overweight, it is appropriate to consider that preventing excess growth in later childhood may be as important for reducing adult ill-health as supporting fetal-infant growth.

\section{Acknowledgments}

This study was a collaboration between the Karolinska Institute, Stockholm, Sweden and University of Nigeria Teaching Hospital, Enugu,

\section{References}

1. Unwin N (2001) Non-communicable disease and priorities for health policy in sub-Saharan Africa. Health Policy Plan 16: 351-352.

2. Yach D, Hawkes C, Gould CL, Hofman KJ (2004) The global burden of chronic diseases: overcoming impediments to prevention and control. JAMA 291: 2616-2622.

3. Barker DJP (1998) Mothers, babies and health in later life. Edinburgh: Churchill Livingstone.

4. Gluckman PD, Hanson MA, Bateson P, Beedle AS, Law CM, et al. (2009) Towards a new developmental synthesis: adaptive developmental plasticity and human disease. Lancet 373: 1654-1657.

5. Barker DJ, Gluckman PD, Godfrey KM, Harding JE, Owens JA, et al. (1993) Fetal nutrition and cardiovascular disease in adult life. Lancet 341: 938-941.

6. Bergvall N, Iliadou A, Johansson S, de Faire U, Kramer MS, et al. (2007) Genetic and shared environmental factors do not confound the association between birth weight and hypertension: a study among Swedish twins. Circulation 115: 2931-2938.

7. Kaijser M, Bonamy AK, Akre O, Cnattingius S, Granath F, et al. (2009) Perinatal risk factors for diabetes in later life. Diabetes 58: 523-526.

8. [No authors listed] (1991) Underlying and proximate determinants of child health: the Cebu Longitudinal Health and Nutrition Study. Am J Epidemiol 133: 185-201.

9. Ravelli AC, van der Meulen JH, Michels RP, Osmond C, Barker DJ, et al. (1998) Glucose tolerance in adults after prenatal exposure to famine. Lancet 351 : $173-177$.

10. Ravelli AC, van Der Meulen JH, Osmond C, Barker DJ, Bleker OP (1999) Obesity at the age of $50 \mathrm{y}$ in men and women exposed to famine prenatally. Am J Clin Nutr 70: 811-816.

11. Roseboom TJ, van der Meulen JH, Ravelli AC, van Montfrans GA, Osmond C, et al. (1999) Blood pressure in adults after prenatal exposure to famine. J Hypertens 17: 325-330.

12. Roseboom TJ, van der Meulen JH, van Montfrans GA, Ravelli AC, Osmond C, et al. (2001) Maternal nutrition during gestation and blood pressure in later life. J Hypertens 19: 29-34.

13. Victora CG, Adair L, Fall G, Hallal PC, Martorell R, et al. (2008) Maternal and child undernutrition: consequences for adult health and human capital. Lancet 371: $340-357$.

14. Bhargava SK, Sachdev HS, Fall CH, Osmond C, Lakshmy R, et al. (2004) Relation of serial changes in childhood body-mass index to impaired glucose tolerance in young adulthood. N Engl J Med 350: 865-875.

15. Richter LM, Norris SA, De Wet T (2004) Transition from Birth to Ten to Birth to Twenty: the South African cohort reaches 13 years of age. Paediatr Perinat Epidemiol 18: 290-301.

16. Sachdev HS, Fall CH, Osmond C, Lakshmy R, Dey Biswas SK, et al. (2005) Anthropometric indicators of body composition in young adults: relation to size at birth and serial measurements of body mass index in childhood in the New Delhi birth cohort. Am J Clin Nutr 82: 456-466.

17. Victora GG, Barros FG, Lima RC, Behague DP, Gon alves H, et al. (2003) The Pelotas birth cohort study, Rio Grande do Sul, Brazil, 1982-2001. Cad Saude Publica 19: 1241-1256.
Nigeria. Field work in Enugu could not have been completed in time without the undermentioned members of Medix Frontiers whose invaluable contribution ensured a successful collection of data for the research: Igwedimma Michael, Ezekekwu Chinedu, Besongngem Akotanchi, Moeteke Nnamdi S, Dr. Ilomuanya Uchenna S., Alozie Izima C., Osi Sixtus S., Odumegwu Chidi A, Odiakosa Otito R., Ezenduka Johnbaptist, Awuzie Nonye P.,Ugwoke Kenneth, Ijemba Obiora C. E., Adugo Christian C., Orogwu Ifedichimma, Obumneme Chinweuba, Okechukwu Valentine, Nworgu Chinemerem, Eze Maduabuchi N., Bassey Joshua Ihemelandu, Aneke Ifeoma O., Unachukwu Chinonyerem, Elosiuba Emeka, Mba Martins, Iwuchukwu Izuchukwu, Akande Ifeoluwa, Ijeoma Austin, Ohanu Uzoamaka, Awoh Benita, Agwu Uchechukwu, Onah Chiamaka, Njeze Nneze, Onwumere Nnenna M., Enwereji Amarachi, Okpara Valentine, Agu Chinenye, Ebere Ikenna, Nwafor Nkemjika Peace, Nwosu Nneka Ifunanya, Ifeanyichi Martilord,Ihediora Amarachi, Okutepa Ocholi G., Nwose Sunday Onyemaechi, Umeh Arinze, Nwankwo kosiso O., Akalawu Martins, Nwatuzor Christopher and Ewelukwa Chukwudum.

\section{Author Contributions}

Conceived and designed the experiments: MH PT PU CG AKEB BO MN. Performed the experiments: MH PT PU CG BO. Analyzed the data: MH PT PU AKEB MN. Wrote the paper: MH PT PU CG AKEB BO $\mathrm{MN}$.

18. Grajeda R, Behrman JR, Flores R, Maluccio JA, Martorell R, et al. (2005) The human capital study 2002-04: tracking, data collection, coverage, and attrition. Food Nutr Bull 26: S15-24.

19. Stanner SA, Bulmer K, Andres C, Lantseva OE, Borodina V, et al. (1997) Does malnutrition in utero determine diabetes and coronary heart disease in adulthood? Results from the Leningrad siege study, a cross sectional study. BMJ 315: 1342-1348.

20. Barker DJ, Eriksson JG, Forsen T, Osmond C (2002) Fetal origins of adult disease: strength of effects and biological basis. Int J Epidemiol 31: 1235-1239.

21. Hales CN, Barker DJ, Clark PM, Cox LJ, Fall C, et al. (1991) Fetal and infant growth and impaired glucose tolerance at age 64. BMJ 303: 1019-1022.

22. Eriksson J, Forsen T, Tuomilehto J, Osmond C, Barker D (2000) Fetal and childhood growth and hypertension in adult life. Hypertension 36: 790-794.

23. Koupil I, Shestov DB, Sparen P, Plavinskaja S, Parfenova N, et al. (2007) Blood pressure, hypertension and mortality from circulatory disease in men and women who survived the siege of Leningrad. Eur J Epidemiol 22: 223-234.

24. Stein AD, Zybert PA, van der Pal-de Bruin K, Lumey LH (2006) Exposure to famine during gestation, size at birth, and blood pressure at age $59 \mathrm{y}$ : evidence from the Dutch Famine. Eur J Epidemiol 21: 759-765.

25. Ike SO (2009) Prevalence of hypertension and its complications among medical admissions at the University of Nigeria Teaching Hospital, Enugu (Study 2). Niger J Med 18: 68-72.

26. Holmes MD, Dalal S, Volmink J, Adebamowo CA, Njelekela M, et al. (2010) Non-communicable diseases in sub-Saharan Africa: the case for cohort studies. PLoS Med 7(5): e1000244.

27. Black RE, Allen LH, Bhutta ZA, Caulfield LE, de Onis M, et al. (2008) Maternal and child undernutrition: global and regional exposures and health consequences. Lancet 371: 243-260.

28. Miller JP (1970) Medical relief in the Nigerian civil war. Lancet 760: 1330-1334.

29. Aall C (1970) Relief, nutrition and health problems in the Nigerian-Biafran war. J Trop Pediatr 16: 70-90.

30. Topouchian JA, El Assaad MA, Orobinskaia LV, El Feghali RN, Asmar RG (2006) Validation of two automatic devices for self-measurement of blood pressure according to the International Protocol of the European Society of Hypertension: the Omron M6 (HEM-7001-E) and the Omron R7 (HEM 637IT). Blood Press Monit 11: 165-171.

31. Report of a WHO/International Diabetes Federation consultation (2006) Definition and diagnosis of diabetes mellitus and intermediate hyperglycemia. ISBN 9241594934.

32. Adair LS, Cole TJ (2003) Rapid child growth raises blood pressure in adolescent boys who were thin at birth. Hypertension 41: 451-456.

33. Huxley RR, Shiell AW, Law CM (2000) The role of size at birth and postnatal catch-up growth in determining systolic blood pressure: a systematic review of the literature. J Hypertens 18: 815-831.

34. Leon DA, Koupilova I, Lithell HO, Berglund L, Mohsen R, Vagero D, Lithell UB, McKeigue PM (1996) Failure to realise growth potential in utero and adult obesity in relation to blood pressure in 50 year old Swedish men. BMJ 312: 401-6. 
35. Armitage JA, Khan IY, Taylor PD, Nathanielsz PW, Poston L (2004) Developmental programming of the metabolic syndrome by maternal nutritional imbalance: how strong is the evidence from experimental models in mammals? J Physiol 561: 355-377.

36. Gluckman PD, Hanson MA (2004) Living with the past: evolution, development, and patterns of disease. Science 305: 1733-1736.

37. Moore SE, Halsall I, Howarth D, Poskitt EM, Prentice AM (2001) Glucose, insulin and lipid metabolism in rural Gambians exposed to early malnutrition. Diabet Med 18: 646-653.

38. Lucas A, Fewtrell MS, Cole TJ (1999) Fetal origins of adult disease - the hypothesis revisited. BMJ 319: 245-9.

39. Lawlor DA, Ebrahim S, Davey Smith G (2002) Is there a sex difference in the association between birth weight and systolic blood pressure in later life? Findings from a meta-regression analysis. Am J Epidemiol 156: 1100-1104.

40. Shepherd PR, Crowther NJ, Desai M, Hales CN, Ozanne SE (1997) Altered adipocyte properties in the offspring of protein malnourished rats. Br J Nutr 78: $121-129$.

41. Huxley R, Neil A, Collins R (2002) Unravelling the fetal origins hypothesis: is there really an inverse association between birthweight and subsequent blood pressure? Lancet 360: 659-665.
42. Clausson B, Lichtenstein P, Cnattingius S (2000) Genetic influence on birthweight and gestational length determined by studies in offspring of twins. BJOG 107: 375-381.

43. Nwagwu MO, Cook A, Langley-Evans SC (2000) Evidence of progressive deterioration of renal function in rats exposed to a maternal low-protein diet in utero. Br J Nutr 83: 79-85.

44. Blum JD (1969) Who cares about Biafra anyway? The Harvard Crimson. February 25.

45. Sani MU, Wahab KW, Yusuf BO, Gbadamosi M, Johnson OV, et al. (2010) Modifiable cardiovascular risk factors among apparently healthy adult Nigerian population - a cross sectional study. BMC Res Notes 3: 11.

46. Oladapo OO, Salako L, Sodiq O, Shoyinka K, Adedapo K, et al. (2010) A prevalence of cardiometabolic risk factors among a rural Yoruba south-western Nigerian population: a population-based survey. Cardiovasc J Afr 21: 26-31.

47. Johansson S, Norman M, Legnevall L, Dalmaz Y, Lagercrantz H, et al. (2007) Increased catecholamines and heart rate in children with low birth weight: perinatal contributions to sympathoadrenal overactivity. J Intern Med 261: 480-487.

48. Yusuf S, Sleight P, Pogue J, Bosch J, Davies R, et al. (2000) Effects of an angiotensin-converting-enzyme inhibitor, ramipril, on cardiovascular events in high-risk patients. The Heart Outcomes Prevention Evaluation Study Investigators. N Engl J Med 342: 145-153. 